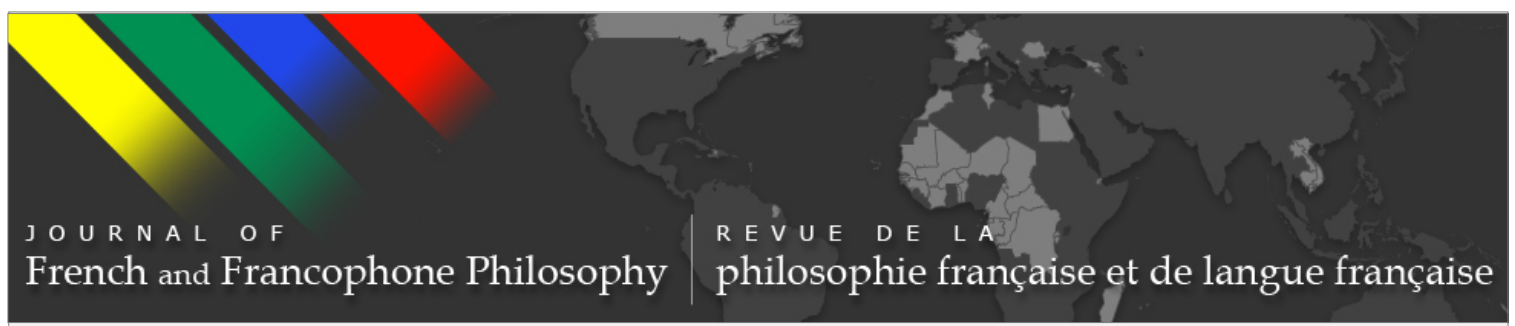

\title{
Introduction
}

\section{Forum on Creolizing Theory}

\section{Lewis R. Gordon}

Journal of French and Francophone Philosophy - Revue de la philosophie française et de langue française, Vol XXV, No 2 (2017) pp 1-5.

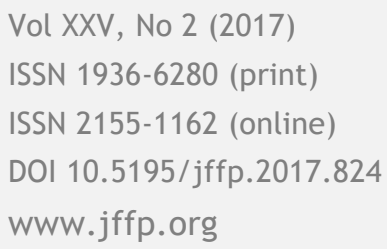

\section{(oc) EY-NG-ND}

This work is licensed under a Creative Commons Attribution-Noncommercial-No Derivative Works 3.0 United States License.

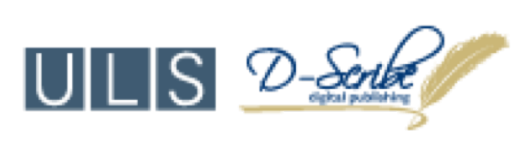

This journal is operated by the University Library System of the University of Pittsburgh as part of its D-Scribe Digital Publishing Program, and is co-sponsored by the University of Pittsburgh Press 


\title{
Introduction
}

\section{Forum on Creolizing Theory}

\author{
Lewis R. Gordon
}

UCONN-Storrs; Global Center for Advanced Study; Rhodes University

On a beautiful August afternoon in 2006 in the city of Montreal, Canada, Jane Anna Gordon presented a paper, "Of Legitimation and the General Will: Creolizing Rousseau through Fanon," at the Caribbean Philosophical Association's international conference. ${ }^{1}$ Gordon was also the organizer of the session, entitled Creolizing Rousseau, and her co-presenters were Charles Mills and Neil Robert with Natalija Mićunović serving as moderator. The audience included Enrique Dussel, Patrick Goodin, Barnor Hesse, Paget Henry, and Michael Monahan, among others. Gordon was not aware at the time that she was inaugurating a movement in political theory and, as that research grew, across the social sciences into new work in the humanities. It wasn't that scholars had not thought about creolism, Creolité, creolization, and creole theory before. As her subsequent book, Creolizing Political Theory, makes clear: Those formulations have a rich history from the early stages of Euromodernity in the Caribbean through to the moment of her presentation. ${ }^{2}$ What was different about her work, however, were the at-first synthetic aims of her project brought to the level of metatheory. Initially motivated by explorations in comparative political theory, Gordon quickly concluded shortcomings with discourses of "comparative politics." Such political theory, she observed, worked within a framework if East-West movements of thought, in older, Hegelian formulations Geist or Spirit, and less ostentatiously, reason. Such a formulation often elided, and at worst occluded, the possibility of what Juliet Hooker recently coined "hemispheric juxtaposition," that is, NorthSouth, multidirectional movements, influences, and mixtures of thought. ${ }^{3}$ As the Caribbean Philosophical Association's motto is "shifting the geography of reason," the burning subtext of Gordon's 2006 intervention was: Wither the Global South? Or, to put it more specifically, in the dialogue and comparisons between the European and the Asian, where stood the Africans, the Oceanic peoples, and the Amerindians not only in the movement of thought but also the theorizing of what it means to think?

Journal of French and Francophone Philosophy | Revue de la philosophie française et de langue française Vol XXV, No 2 (2017) | www.jffp.org | DOI 10.5195/jffp.2017.824 
Gordon's paper stimulated reflection among members of the 2006 audience, which led to some of them publishing various explorations of creolization in political theory and political philosophy. Though her focus in that meeting was on connections between Fanon and Rousseau, Gordon's first published exploration of her theory was through putting W.E.B. Du Bois, Fanon, Rousseau, and Max Weber in conversation on problems of legitimacy, and then collaboration with Neil Roberts, one of the attendees at that meeting, for The C.L.R. James Journal's special issue on creolizing Rousseau. ${ }^{4}$ The result has been a steady stream of critical discussions of creolization in political theory and political philosophy, which include Michael Monahan's The Creolizing Subject and "Symptomatically Black: The Creolization of Black Thought" by Barnor Hesse, who brought some of the ideas from that 2006 meeting to his contribution to Françoise Lionnet and Shu-mei Shih's anthology, The Creolization of Theory. ${ }^{5}$ Gordon, however, continued her research culminating into what is to date the most systematic account-namely, her Creolizing Political Theory: Reading Rousseau through Fanon, which offers a radically different understanding, as the reader will see in the discussions below, than what was up to that point understood as the creolization of theory. ${ }^{6} \quad$ The explosion of work inaugurated by this next phase of Gordon's work, which came to print during her presidency of the Caribbean Philosophical association, led also to the series she co-founded at Rowman \& Littlefield International in London with the current president of the organization, Neil Roberts: Creolizing the Canon. Gordon also co-founded, with Nelson Maldonado-Torres (the president who preceded her) and this author, a related series, Global Critical Caribbean Thought with the same press, and she has written elaborations of her thought in a variety of publications. ${ }^{7}$

The impact of this now more than a decade's work of theorizing and scholarship is evident in the many global forums in which the ideas have become a crucial part of how work is done in a variety of disciplines, as one would think creolizing intellectual work should be. It is with that observation that I've taken the time to organize this forum. As an important development in contemporary theory, it struck me that creolizing political theory should be placed in dialogue with some of the creative formulations of theory animated from the similar spirit as Gordon's concerns from 2006 onward. I thus assembled a community of scholars with the task not of commenting on Gordon's work but instead placing it in dialogue with their own. The idea is that the value of theory depends also on the extent to which it could be engaged in a communicative practice with other theories dedicated to a shared concern. In this case, it is scholars committed to thought devoted to concerns of dignity, freedom, and liberation as well as the critical question of the ultimate value of doing theoretical work.

The theorists assembled here were thus chosen also on the basis of the value of their own thought. It struck me that if Gordon is correct about creolization, engaging her ideas should offer the felicitous outcome of 
learning about the ideas of those who take on that endeavor. I was also curious whether an engagement with the problem of creolizing theory would entail a form of creolization of the theory that does so, and even if that were not the case, it was my hope that the readers of this forum gain an appreciation of some of the outstanding theoretical work going on from the Global South, which, as the constellation of thinkers assembled here should illustrate, transcends a geographical location. This is theory beyond the form of Northern-centrism that produced notions such as "Western" and "Occident." Since these ideas in effect particularize such thought through pointing out their failure to be relational—that is, taking on the dialectical task of what is to be done when false-universals are acknowledged-the communicative practice offered here exemplifies what Paget Henry calls "potentiated double consciousness": the universalizing activity of establishing relations without closure. ${ }^{8}$ This possibility of theorizing, in critical, transformative movements, is what this forum offers.

It begins with Michael Neocosmos, whose Thinking Freedom in Africa is a recent winner of the Caribbean Philosophical Association's Frantz Fanon Outstanding Book Award. ${ }^{9}$ Neocosmos offers, through his work on the creativity and reflection of everyday people in Africa and the Caribbean, a plea for a synthesis of creolization with dialectics. Next, Nathalie Etoke, whose Africana melancholia won the Fanon award in 2012, examines the ironic situation of French society's claims for inclusion while its center fights vehemently against processes of creolization. ${ }^{10}$ The melancholia of which she writes speaks to the produced subjectivity alienated by and from its indigenous origins. These reflections are followed by Kevin Bruyneel's work on settler memory, history, and questions of Indigenous sovereignty, where, drawing on Du Bois's critique of racist historiography, a form of antihistory is at the core of erasing the significance of de facto relationality-in a word, creolization. Inspired by Gordon's productive creolization of Fanon and Rousseau, the social theorist Sonia Dayan-Herzbrun, who won the Fanon Lifetime Achievement Award in 2014, raises the question of a productive meeting of Ngũgĩ wa Thiongo's critical concerns on the decolonization of language and Karl Marx's revolutionary critique of ideology as an exemplification of the creolizing of theory. Ngũgĩ wa Thiong'o's exemplification of indigenous and racial concerns-exemplified in the African in Africa-also raises pressing questions of authenticity, at least through language, on one hand and yet a challenge to it beyond translation into global conversation on the other, which links to DayanHerzbrun's commitments to the possibility of critical theory as an open and ethical dialectical practice. Gordon joins the conversation as the culmination of a decade's work now standing as-in the significance of the prophetic name of her youngest son Elijah, for whom one opens a door during Passover, and the metaphor of the Zulu name "Sula," which, though most known through Toni Morrison's eponymous novel, is also the name of one of Gordon's daughters-a proverbial new beginning.

位 Vol XXV, No 2 (2017) | http://www.jffp.org | DOI 10.5195/jffp.2017.824 
1 Unpublished. "Of Legitimation and the General Will: Creolizing Rousseau through Fanon." Shifting the Geography of Reason III: Aesthetics, Science, and Language. Caribbean Philosophical Association. Montreal, Canada. August 2006.

2 Jane Anna Gordon, Creolizing Political Theory: Reading Rousseau through Fanon (New York: Fordham University Press, 2014).

3 Juliet Hooker, Theorizing Race in the Americas: Douglass, Sarmiento, Du Bois, and Vasconcelos (New York: Oxford University Press, 2017).

4 Jane Anna Gordon, "Double Consciousness and the Problem of Legitimacy in Political Thought," in Lewis R. Gordon and Jane Anna Gordon (eds.), Not Only the Master's Tools: African-American Studies in Theory and Practice (New York: Routledge, 2006), 205-225, and Jane Anna Gordon and Neil Roberts (eds.), Creolizing Rousseau (London: Rowman and Littlefield International); revised and expanded version of The C.L.R. James Journal 15, no. 1 (Spring 2009): 1-300.

${ }^{5}$ Michael J. Monahan, The Creolizing Subject: Race, Reason, and the Politics of Purity (New York: Fordham University Press, 2011); Barnor Hesse, "Symptomatically Black: The Creolization of the Political," in Françoise Lionnet and Shu-mei Shih (eds.), The Creolization of Theory (Durham: Duke University Press, 2011), 37-61.

6 See Jane Anna Gordon, "Revolutionary in Counter-Revolutionary Times: Elaborating Fanonian National Consciousness into the Twenty-First Century," Journal of French and Francophone Philosophy-Revue de la philosophie française et de langue francaise XIX, no. 1 (2011): 37-47; “Of Force, Power, and Will: Rousseau and Fanon on Democratic Legitimacy," in Nigel Gibson (ed.), Living Fanon: Global Perspectives (New York: Palgrave, 2011), 201-211; “The General Will and National Consciousness: Radical Requirements of Democratic Legitimacy in the Writing of Rousseau and Fanon," in Mikkel Thorup and Holger Ross Lauritsen (eds.), Rousseau and Revolution (London: Continuum, 2011), 31-50; and Creolizing Political Theory.

7 "Creolising Political Identity and Social Scientific Method: An Essay in Celebration of CODESRIA's 40 ${ }^{\text {th }}$ Year," Africa Development XXXIX, no. 1 (2014): 65-80; "Creolizing as the Transdisciplinary Alternative to Intellectual Legitimacy on the Model of the 'Normal Scientific' Community," Quaderna: A Multilingual and Transdisciplinary Journal, $\mathrm{n}^{\circ}$ 3: url permanente: http://quaderna.org/creolizing-asthe-transdisciplinary-alternative-to-intellectual-legitimacy-on-the-model-of-thenormal-scientific-community/; and "Par-delà la seule critique: Créoliser nos entreprises intellectuelles et politiques," Revue Tumultes, ${ }^{\circ} 48$ (2017): 19-38.

Journal of French and Francophone Philosophy | Revue de la philosophie française et de langue française Vol XXV, No 2 (2017) | http://www.jffp.org | DOI 10.5195/jffp.2017.824 
${ }^{8}$ Paget Henry, Journeys in Caribbean Thought: The Paget Henry Reader, Jane Anna Gordon, Lewis R. Gordon, Aaaron Kamugisha, Neil Roberts, and Paget Henry (eds.) (London: Rowman \& Littlefield International, 2017).

${ }^{9}$ Michael Neocosmos, Thinking Freedom in Africa: Toward a Theory of Emancipatory

Politics (Johannesburg, SA: Wits University Press, 2016):

http:/ / witspress.co.za/news/announcement-thinking-freedom-in-africa-is-one-of-

the-2017-frantz-fanon-outstanding-book-award-winners/.

${ }^{10}$ Nathalie Etoke, Melancholia Africana (Paris: Editions du Cygne, 2010). For the list of all the Frantz Fanon award winners through to 2017, see: http://www.caribbeanphilosophicalassociation.org/frantz-fanon-prize.html 